\title{
THE RELATION BETWEEN EXTERNAL AUDIT FEES, AUDIT \\ COMMITTEE CHARACTERISTICS AND INTERNAL AUDIT
}

\begin{abstract}
This study examines the association between audit fees, an effective audit committee and internal audit in an Australian setting. We find significant positive associations between the level of audit fees and the existence of an audit committee, the use of internal audit, and audit committee meeting frequency. We also find a significant 3way interaction between audit committee independence, expertise and meeting frequency. Additional analysis indicates that expertise is positively associated with audit fees only when meeting frequency and independence are low. This is consistent with audit committee members with accounting expertise demanding a higher level of assurance in these circumstances.
\end{abstract}




\section{THE RELATION BETWEEN EXTERNAL AUDIT FEES, AUDIT \\ COMMITTEE CHARACTERISTICS AND INTERNAL AUDIT}

\section{Introduction}

This paper answers the following research question. Do audit committee characteristics and use of internal audit explain an increased demand for a higher quality audit indicated by higher audit fees? This question is important because the current focus on corporate governance has directed attention on the roles played by internal and external auditors and audit committees in reducing the risk of the auditor providing an incorrect audit opinion (McElveen, 2002). Previous studies in the United States (US) provide conflicting results (Carcello et al. 2002, Abbott et al. 2003. Our study is undertaken in the Australian setting when the existence of audit committees is voluntary.

Early studies of the association between audit committees and audit fees focused on the presence of an audit committee (Collier and Gregory, 1996; Goddard and Masters, 2000; Coulton et al., 2001). More recent studies have examined the association between audit fees and audit committee characteristics such as the independence and expertise of committee members and the frequency of meetings (Carcello et al., 2002; Abbott et al., 2003; Sharma, 2003). While most studies predict that an effective audit committee should demand a higher quality audit, counter arguments have been presented that such a committee should reduce the auditor's risk assessment, resulting in the need for less testing (Collier and Gregory, 1996; Goddard and Masters, 2000; Abbott et al., 2003). The results of these prior studies have been mixed but have tended to support a positive association between audit fees and an effective audit committee. 
The relation between internal audit and audit fees has also received attention from researchers. Some studies suggest that internal audit and external audit are substitutes for one another (Elliott and Korpi, 1978; Wallace, 1984; Felix et al., 2001). However, other studies suggest that the two types of audit may be complementary, with an increase in both when greater monitoring is required (Carey et al., 2000a; Hay and Knechel, 2002). These two notions are not mutually exclusive as internal audit may substitute for some external audit work within a general framework of stronger governance.

We contribute to the growing body of literature in this area in a number of ways. The two US studies which we replicate have produced conflicting results, with Abbott et al. (2003) finding a positive association between audit fees and audit committee independence and expertise and Carcello et al. (2002) finding that the association does not hold in the presence of board characteristics. Our study is undertaken in an institutional environment where corporate governance is less regulated than the US ${ }^{1}$ (von Nessen, 2003; Davidson et al., 2005). The setting is therefore closer to that of Carcello et al. (2002) who used 1992-93 US data. However, the Australian setting involves firms that are smaller in size than those in the US (Holland and Ramsay, 2003). Further, while we replicate the audit fee models used in prior US studies, we also develop other models which include additional control variables and alternative measures of audit committee effectiveness. Finally, a unique contribution of our

\footnotetext{
1 The Government's Corporate Law Economic Reform Program (CLERP 9, 2004), now requires mandatory audit committees for the Top 500 listed companies. Further, the Australian Stock Exchange (ASX) amended its listing rules in 2003 to require any company that was included in the S\&P/ASX All Ordinaries Index at the beginning of its financial year to have an audit committee during that year. In addition, the ASX Corporate Governance Council (2003) recommends that all companies have an audit
} 
study is the inclusion of internal audit as a governance mechanism in conjunction with the audit committee variables. ${ }^{2}$

We find a positive association between the level of audit fees and the existence of an audit committee. Our results also indicate a positive association between audit fees and the frequency of audit committee meetings but we do not find a significant association between audit fees and audit committee independence or expertise. However, we find a significant 3-way interaction between independence, expertise and frequency of meetings. Additional analysis of the interaction term indicates that expertise is positively associated with audit fees but only when both meeting frequency and independence are low. This result is consistent with a demand by audit committee members with accounting expertise for a higher level of assurance in these circumstances. This suggests that independence, expertise and meeting frequency play a complementary role in enhancing the effectiveness of the audit committee with respect to audit quality. However, the relationship is clearly complex and warrants further research.

Our results differ from Abbott et al. (2003) and Carcello et al. (2002) in the United States (US) and Goddard and Masters (2000) in the United Kingdom (UK), questioning the generalisability of these studies to the Australian regulatory environment. Further, our findings concerning the interaction between the audit committee effectiveness variables differ to those of Sharma (2003) who finds a

committee. However, in the year of our study (2000), there was no requirement to have either an audit committee or an internal audit function.

${ }^{2}$ While the benefits of having an internal audit function have been noted (PricewaterhouseCoopers, 1999; Australian Accounting Research Foundation, Australian Institute of Company Directors and the Institute of Internal Auditors - Australia, 2001), many listed companies in Australia still do not use internal audit (Carey et al., 2000a; Goodwin and Kent, 2003). 
relationship between audit fees and audit committee independence and expertise only when meeting frequency is high. These differences may be due to the larger sample size used in our study and the inclusion of smaller companies in our sample.

Finally, we also find a positive association between the level of audit fees and the use of internal audit. This result suggests that firms that engage in greater internal monitoring also engage in greater external monitoring, with the implication that directors of these firms recognise the importance of both types of audit as mechanisms to strengthen corporate governance.

The remainder of the paper is structured as follows. The next section discusses the background to the study, followed in the third section by a description of the research design. The results of our study are reported in the fourth section while in the final section some conclusions are drawn and the implications of the study are discussed.

\section{Background}

\subsection{Audit Committees and Audit Fees}

The relationship between audit committees and external audit is a complex one, stemming from both the demand for audit services by the client and the supply of audit services by the external auditor (Collier and Gregory, 1996). From the demand side, the presence of an audit committee may have a positive association with audit fees by ensuring that audit hours are not reduced to a level that compromises the quality of the audit. ${ }^{3}$ Not only is this considered to be an important role of audit committees (Cadbury Committee, 1992; Jack, 1993), but audit committee members 
have incentives to ensure a high quality audit in order to reduce the risk of litigation and the loss of reputation in the event of fraudulent financial reporting.

From the supply side, the audit committee's involvement in strengthening internal controls may lead the external auditor to reduce the assessed level of control risk. As a consequence, the auditor's reliance on internal controls should result in less substantive testing and hence a lower audit fee (Collier and Gregory, 1996). ${ }^{4}$ This could be negated, however, by an increase in audit hours resulting from the need for the audit partner to liaise regularly with the audit committee, attend audit committee meetings throughout the year and prepare reports for the committee. Goodwin and Munro (2004) find that audit partners and managers believe that the presence of an audit committee has little impact on the level of audit testing but that audit fees are greater as a result of increased partner and manager time.

A further reason for a positive relation between audit fees and an audit committee is that an effective committee should reduce the threat of auditor dismissal and therefore could strengthen the auditor's bargaining position during fee negotiations (Abbott et al., 2003).

Two UK studies and two Australian studies have examined the impact of audit committees on audit fees. Collier and Gregory (1996), using 1991 UK data, find an increasing effect of audit committees on the size-related audit fee, but find only weak support for a decreasing effect based on the complexity and risk-related audit fee. In a post-Cadbury replication of the Collier and Gregory (1996) study, Goddard and

\footnotetext{
${ }^{3}$ Collier and Gregory (1996) describe this as a "size-related audit fee”.
} 
Masters (2000) find no evidence of higher size-related audit fees for UK companies with audit committees. They also find inconclusive and conflicting results concerning complexity and risk-related audit fees and the existence of an audit committee. Sharma (2003), using a sample drawn from the top 500 listed companies in Australia, finds a significant positive association between audit fees and the existence of an audit committee. Coulton et al. (2001) also find a positive association between the level of audit fees and the existence of an audit committee, using a sample of 614 industrial companies listed on the ASX in 1998.

We contend that the arguments for a positive relation between the existence of an audit committee and audit fees outweigh those for a negative relation. Both demand and supply side arguments exist for a positive relation and only one supply side argument for a negative relation. Further, the results of prior research provide support for a positive association. We therefore test the following hypothesis:

H1: There is a positive association between the external audit fee and the existence of an audit committee.

Prior research suggests that "key audit committee characteristics - rather than the mere presence of an audit committee - critically impact the audit committee's ability to effectively execute its duties” (Abbott et al., 2003, p. 20).

Regulators emphasise the need for audit committees to be comprised of members who are independent and at least some of whom have financial expertise. They also recognise the need for audit committees to meet frequently in order to effectively

\footnotetext{
${ }^{4}$ Collier and Gregory (1996) describe this as a “complexity and risk-related audit fee”.
} 
carry out their duties (Blue Ribbon Committee (BRC), 1999; New York Stock Exchange (NYSE), 2002; ASX Corporate Governance Council, 2003). This is supported by the results of research studies which show that these characteristics impact audit committee effectiveness (Beasley et al., 2000; Carcello and Neal, 2000; DeZoort and Salterio, 2001; Abbott et al., 2004). Abbott et al. (2003) argue that independent audit committee members may both demand a higher level of assurance and also support the auditor's demand for more testing, leading to an increase in audit fees. This support is likely to be greater when committee members have the financial and auditing expertise that enables them to better understand the risks associated with a lower quality audit. Further, audit committees that meet frequently are likely to be better informed and more diligent in performing their duties.

The results of prior studies examining the relation between audit fees and audit committee effectiveness have, however, been inconsistent. As noted, Carcello et al. (2002), using US data from the early 1990s, find that board characteristics rather than audit committee characteristics are associated with higher audit fees. In contrast, Abbott et al. (2003), using more recent US data, report a significant positive association between audit committee independence and expertise and audit fees, but no significant association between meeting frequency and audit fees. In spite of these conflicting findings, we predict that a strong and active audit committee is positively associated with a higher quality audit, demonstrated by a higher level of audit fees. This gives rise to the following hypothesis:

H2: There is a positive association between the external audit fee and the strength and activity of the audit committee. 
Sharma (2003), using Australian data, finds a significant positive association between audit fees and a 3-way interaction between independence, expertise and meeting frequency. A possible explanation for this result is that there is a tradeoff between audit committee diligence and the independence and/or expertise of members of the committee. For example, meeting more frequently, particularly if the audit partner is present at those meetings, may compensate for a lack of formal accounting expertise by members or for the presence of executives on the audit committee. We therefore explore whether Sharma’s (2003) finding holds for our larger and more varied sample of companies. However, because the relationships between the three audit committee variables are likely to be complex, we explore the possibility of interaction effects without predicting a direction. This leads to the following hypothesis:

H3: There is an association between the external audit fee and the interaction between audit committee independence, expertise and meeting frequency.

\subsection{Internal Audit and Audit Fees}

Only a few studies have examined the relation between internal audit and external audit fees and results have been mixed. Elliott and Korpi (1978) and Felix et al. (2001) find a negative association between audit fees and the contribution of internal audit to the external audit. In both studies, the level of contribution is measured as a continuous variable based on the external auditor's subjective assessment. The findings of these studies suggest that internal audit can be regarded, at least in part, as a substitute for external audit, with a reduction in audit fee being apparent when the external auditor relies on the work of internal audit (Wallace, 1984). The reduction in fees may also be due to a lower assessment of audit risk resulting from internal audit involvement in strengthening internal control. 
In contrast to the findings of Elliott and Korpi (1978) and Felix et al. (2001), both Carey et al. (2000a) and Stein et al. (1994) do not find a significant association between audit fees and the external auditor's assessment of the level of internal audit contribution. Furthermore, studies which focus only on the use of internal audit rather than the level of contribution to the external audit tend to find a positive association between audit fees and the existence of an internal audit function (Carey et al., 2000a; Hay and Knechel, 2002).

These findings suggest that entities may regard internal and external audit as complementary means of increasing the overall level of monitoring. This latter view is consistent with a broader role of internal audit, which in recent years has evolved from a narrow focus on control to embrace risk management and corporate governance (Brody and Lowe, 2000; Carey et al., 2000b; Leung et al., 2004). Hence, while there may be some substitution of internal audit for external audit work, the internal audit function is unlikely to be restricted to activities directly related to the external audit. It is expected therefore that the level of internal auditing is positively related to audit fees because those firms that are more committed to strong corporate governance are likely to engage in greater levels of internal auditing as well as being prepared to pay for a higher quality external audit. This leads to the following hypothesis:

H4: There is a positive association between the external audit fee and the use of internal audit. 


\section{Research Design}

\subsection{Data collection}

Data were collected by undertaking a survey of Australian publicly listed companies and combining the survey data with information disclosed in the annual reports of these companies. A questionnaire was sent to all companies listed on the Australian Stock Exchange in October 2000 (approximately 1400 companies), seeking information on their internal audit activities. After a follow-up request, responses were received from 490 companies, giving a response rate of 35\%. Of these, 26 were unusable because of incomplete data, leaving 464 usable responses. Data from annual reports included both financial variables relating to size, profitability, risk and audit fee and non-financial variables concerning corporate governance, external audit, and the complexity of the entity. We eliminated 29 banks and trusts because of their unique asset structures and specialist audit requirements. Because of missing corporate governance data we eliminated a further 34 companies, thereby reducing our final sample to 401 companies. $^{5}$

To address the possibility of non-response bias, we compared the companies in our sample with the population of listed companies in Australia in 2000. In terms of total assets, the mean size of non-financial listed companies in Australia for that year was $\$ 541$ million, ranging from a minimum of $\$ 53,000$ to a maximum of $\$ 65$ billion. The mean size of the companies in our sample is $\$ 545$ million, ranging from $\$ 65,000$ to $\$ 30$ billion. Further, with respect to profitability, the mean return on assets of nonfinancial listed companies in 2000 was -0.07 , with a minimum of -13.86 and a

\footnotetext{
${ }^{5}$ Databases such as Connect4 and Aspect DatAnalysis were used where possible. For those companies not included in these databases, the actual annual reports were sought either from the internet or directly from the company concerned.
} 
maximum of $0.88 .^{6}$ For the companies in our sample, the mean return on assets is also -0.07 , ranging from -8.86 to 0.61 . While in both cases the range for our sample is slightly smaller than for all listed companies, the companies in our sample come from a good cross-section of industries. All of the two-digit ASX non-financial industry codes are represented. Furthermore, the number of companies in each industry code in the sample is highly correlated with the number in each code in the population of ASX listed companies. ${ }^{7}$

To further test for non-response bias, we conducted t-tests between responses to the first mailout and those received after the follow-up letter was sent. No significant differences were found between early and late responses, suggesting that nonresponse bias is not a problem. ${ }^{8}$

\subsection{Variable Measurement and Model Specification}

To explore our research questions, we use a number of ordinary least squares (OLS) regression models, extending the traditional audit fee model (Simunic, 1980; Francis, 1984; Francis and Simon, 1987; Craswell and Francis, 1999) to include the variables of interest to this study.

\section{Independent Variables}

The variables of interest to the present study are the existence of an audit committee, audit committee independence and expertise, the frequency of audit committee meetings and the use of internal audit.

\footnotetext{
${ }^{6}$ The data on assets and return on assets were obtained from Aspect FinAnalysis for the year 2000.

${ }^{7}$ The Pearson correlation coefficient $=0.923$, at a significance level of $\mathrm{p}=.000$.

${ }^{8}$ Oppenheim (1966) describes this test as an acceptable test for non-response bias, based on the assumption that late respondents are similar to non-respondents.
} 
The existence of an audit committee is a dichotomous variable set at one if the company has an audit committee and zero if there is no audit committee. Audit committee independence is measured as the percentage of independent directors on the committee. A director is assumed to be independent if he/she is a non-executive who has no related party transactions with the company. We exclude those nonexecutives who have related party transactions from our measure following the requirement by the NYSE amended listing standards (NYSE, 2002) that audit committee members must not receive pay from the company (especially consulting fees) other than their regular director fees (Nofsinger and Kim, 2003). ${ }^{9}$ We acknowledge that this measure may include non-executives who have other relationships with the company but we were unable to objectively determine the existence of these relationships from publicly available information. Expertise is measured as the percentage of committee members who have an accounting or finance qualification. ${ }^{10}$ Meeting frequency is the number of audit committee meetings held during the year. This information is disclosed in the directors' report or the corporate governance statement in the annual report.

To test Hypothesis 3, we calculate interaction terms between the three audit committee characteristics. We centre the three effectiveness variables around their means and then determine the interaction terms based on the centred variables. This overcomes correlation problems associated with interactions of continuous variables (Aiken and West, 1991; Jaccard and Turrisi, 2003).

\footnotetext{
${ }^{9}$ This requirement does not extend to non-executive directors who are not members of the audit committee.

${ }^{10}$ The biographical data disclosed in the annual report for each director was perused to identify those with accounting, commerce or business degrees and/or with professional accounting qualifications.
} 
We use the number of employees in internal audit as a proxy for the extent of internal audit use, with those companies not using any internal audit set at zero. Our survey of listed companies asked whether companies have their own internal audit function and the number of employees in the function. The number of employees was chosen as a measure of the size of the internal audit function as this information is less confidential than the internal audit budget and hence is less likely to have a negative impact on the response rate. Because of the existence of a small number of firms with very large internal audit functions, we winsorise this variable to a maximum of 25 staff. $^{11}$

\section{Control Variables}

Audit fee models predict that the principal determinants of audit fees are factors relating to the size, complexity and risk of the client firm (Simunic, 1980; Francis, 1984; Chan et al., 1993). Studies have also found audit fees to be associated with profitability, the type of audit opinion issued, the use of a more reputable audit firm and industry (Francis and Simon, 1987; Chan et al., 1993; Gerrard et al., 1994; Firth, 1997; Craswell and Francis, 1999; Carey et al., 2000a; Ferguson et al., 2003; Casterella et al., 2004). We therefore include a range of variables to control for these factors and these are defined in the next subsection.

We also include control variables for board independence and number of board meetings. Carcello et al. (2002) and Abbott et al. (2003) find a significant positive

\footnotetext{
${ }^{11}$ Four companies had internal audit functions in excess of 25 employees. Two of these had 30 employees, one had 40 and one had 50. Diagnostic tests indicated that these could be considered to be outliers.
} 
association between audit fees and the proportion of outside directors on the board, suggesting that outside directors who act diligently demand a higher quality audit. ${ }^{12,} 13$

\section{Models}

We test our hypotheses using the following models:

\section{Model 1: The existence of an audit committee}

$$
\begin{aligned}
\text { audit fee }= & \mathrm{b}_{0}+\mathrm{b}_{1} \text { size }+\mathrm{b}_{2} \text { subsidiaries }+\mathrm{b}_{3} \text { foreign }+\mathrm{b}_{4} \text { debt }+\mathrm{b}_{5} \text { receivables }+ \\
& \mathrm{b}_{6} \text { inventory }+\mathrm{b}_{7} \text { roa }+\mathrm{b}_{8} \text { loss }+\mathrm{b}_{9} \text { bigfive }+\mathrm{b}_{10} \text { opinion }+\mathrm{b}_{11} \text { mining }+ \\
& \mathrm{b}_{12} \text { boardindep }+\mathrm{b}_{13} \text { boardmeetings }+\mathrm{b}_{14} \text { auditcommittee }+ \\
& \mathrm{b}_{15} \text { internalaudit }+\mathrm{e}
\end{aligned}
$$

Model 2: Audit committee characteristics

$$
\begin{aligned}
\text { audit fee }= & b_{0}+b_{1} \text { size }+b_{2} \text { subsidiaries }+b_{3} \text { foreign }+b_{4} \text { debt }+b_{5} \text { receivables }+ \\
& b_{6} \text { inventory }+b_{7} \text { roa }+b_{8} \text { loss }+b_{9} \text { bigfive }+b_{10} \text { opinion }+b_{11} \text { mining }+ \\
& b_{12} \text { boardindep }+b_{13} \text { boardmeetings }+b_{14} \text { ACindependence }+ \\
& b_{15} \text { ACexpertise }+b_{16} \text { ACmeetings }+b_{17} \text { internalaudit }+e
\end{aligned}
$$

\section{Model 3: Interaction effects between audit committee characteristics}

$$
\begin{aligned}
\text { audit fee }= & b_{0}+b_{1} \text { size }+b_{2} \text { subsidiaries }+b_{3} \text { foreign }+b_{4} \text { debt }+b_{5} \text { receivables }+ \\
& b_{6} \text { inventory }+b_{7} \text { roa }+b_{8} \text { loss }+b_{9} \text { bigfive }+b_{10} \text { opinion }+b_{11} \text { mining }+
\end{aligned}
$$

\footnotetext{
${ }^{12}$ In contrast, Coulton et al. (2001) find a negative association between these variables, but this relation holds only for small firms in their sample of ASX listed industrial companies. They posit that the use of outside directors may be a substitute monitoring mechanism for these firms. We regard the arguments for a positive association to be stronger and therefore predict a positive direction in our regression models.

${ }^{13}$ Both Carcello et al. (2002) and Abbott et al. (2003) also include a board expertise variable, measured as the number of other directorships held by the outside directors. However, we could not obtain reliable information for this variable from published annual reports. The variable is not significant $(\mathrm{p}=$ .946) in the Abbott et al. (2003) study and its omission is unlikely to have a material impact on our results.
} 


$$
\begin{aligned}
& \mathrm{b}_{12} \text { boardindep }+\mathrm{b}_{13} \text { boardmeetings }+\mathrm{b}_{14} \text { ACindependence }+ \\
& \mathrm{b}_{15} \text { ACexpertise }+\mathrm{b}_{16} \text { ACmeetings }+\mathrm{b}_{17} \text { ACindependence*expertise }+ \\
& \mathrm{b}_{18} \text { ACindependence*meetings }+\mathrm{b}_{19} \text { ACexpertise*meetings }+ \\
& \mathrm{b}_{20} \text { ACindependence*expertise*meetings }+\mathrm{b}_{21} \text { internalaudit }+\mathrm{e}
\end{aligned}
$$

where

audit fee

$=\quad$ natural $\log$ of audit fees

size

$=\quad$ natural log of total assets

subsidiaries

$=\quad$ square root of number of subsidiaries

foreign

$=$ ratio of number of foreign subsidiaries to number of subsidiaries

debt

$=\quad$ ratio of non-current liabilities to total assets

receivables

$=\quad$ ratio of receivables to total assets

inventory

$=\quad$ ratio of inventory to total assets

roa

$=\quad$ return on assets measured by earnings before interest

and tax divided by total assets

loss

$=\quad$ a dummy variable given the value 1 if the company has

reported a loss in any of the three years prior to 2000

and 0 otherwise

bigfive

$=\quad$ a dummy variable given the value 1 when a Big Five auditor is used and 0 when a smaller audit firm is used

opinion

$=\quad$ a dummy variable given the value 1 when the audit report is qualified and 0 otherwise

mining

$=\quad$ a dummy variable when the company is in the mining industry and 0 otherwise

boardindep

$=\quad$ the percentage of non-executive directors on the board 


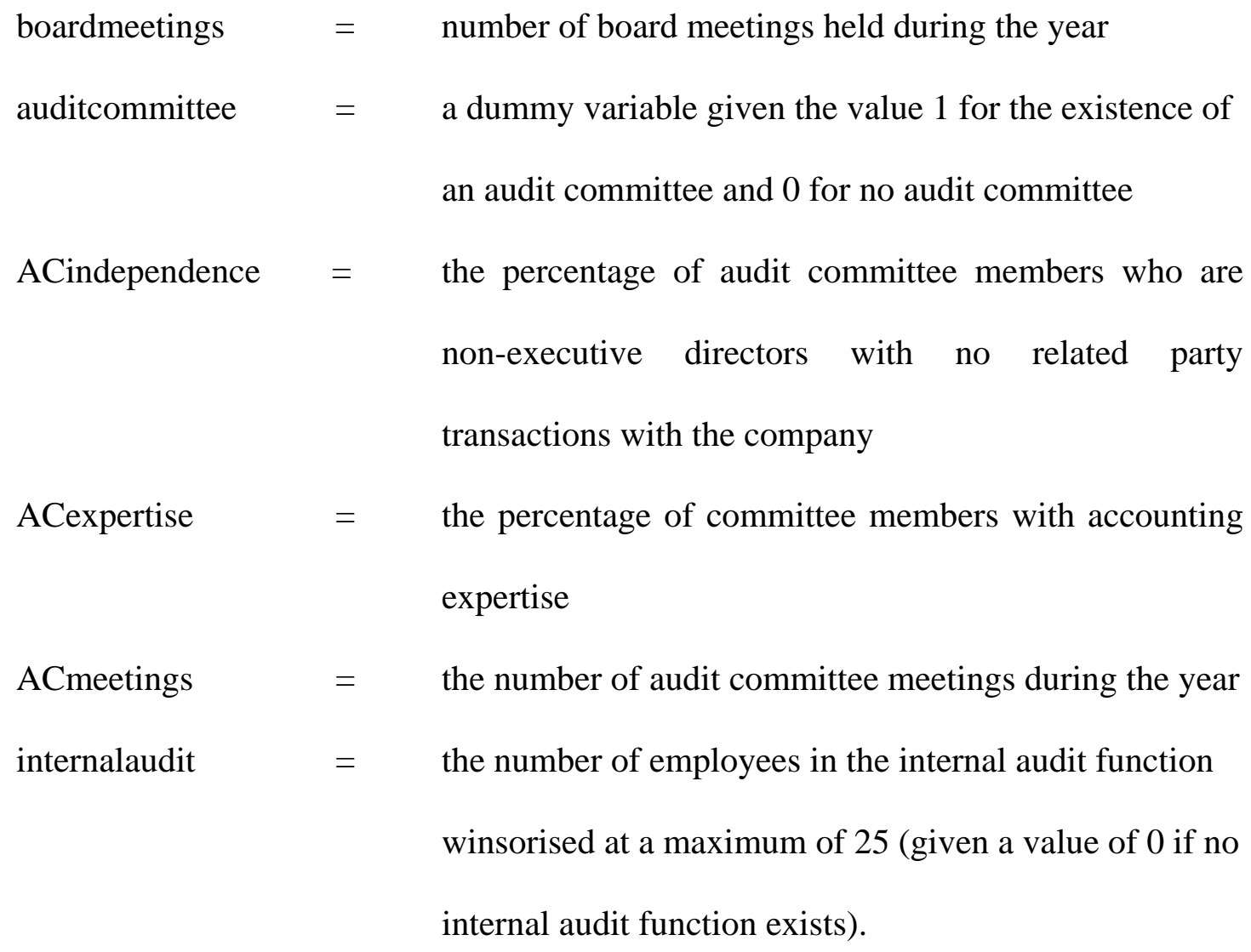

\section{Results}

\subsection{Descriptive statistics}

Table 1 shows descriptive statistics for the variables in the models, with Panel A reporting those for the continuous variables and Panel B reporting those for the dichotomous variables. The mean audit fee for companies in our sample is $\$ 191,129$, ranging from a minimum of $\$ 2,000$ to a maximum of $\$ 6.6$ million. Of particular interest to the study are the audit committee variables and the use of internal audit. Just over three quarters of the sample have an audit committee. This is consistent with previous studies in Australia (Baxter and Pragasam, 1999; Carey et al., 2000a). The mean percentage of audit committee members meeting our test of independence (i.e. non-executive directors who do not have any related party transactions with the 
company) is only 46 percent, ranging from zero to 100 percent. $^{14}$ The mean percentage of members with accounting or finance expertise is $29 \%$, ranging from zero to 100 percent. The number of audit committee meetings held during the year averages two with a minimum of zero and a maximum of 14 . The mean number of employees in internal audit is one, with a maximum number of 50. Approximately two thirds of the sample do not use internal audit.

The relation of each of the variables to the others in the models is shown in Table 2 which reports the correlation coefficients ${ }^{15}$ and levels of significance. While some of the independent variables are significantly correlated with each other, standard diagnostic tests indicate that multicollinearity is not a serious problem.

\subsection{Multivariate statistics}

To test the validity of our models, we first regress audit fees on the control variables only. The untabulated results indicate an adjusted $\mathrm{R}^{2}$ of 0.803 . Consistent with prior studies, audit fees are associated with size, the number of subsidiaries, the proportion of foreign subsidiaries, receivables divided by total assets, the use of a Big Five auditor (all positively associated at $\mathrm{p}=.000$ ), and return on assets (negatively associated at $\mathrm{p}=.050$ ). Audit fees are also negatively associated with our industry variable, indicating that fees tend to be lower for those firms in the mining industry (p $=.000)$. Further, consistent with Carcello et al. (2002), and in contrast to Coulton et al. (2001), we find a significant positive association between audit fees and the proportion of non-executive directors on the board $(p=.008)$. Also consistent with

\footnotetext{
${ }^{14}$ Of interest, the mean percentage of non-executive directors on audit committees is 63\%, indicating that a substantial proportion of non-executives are not truly independent.

${ }^{15}$ SPSS calculates the exact correlation regardless of whether the variables are dummy or continuous.
} 
Carcello et al. (2002), a significant positive association exists between audit fees and the number of board meetings held during the year $(\mathrm{p}=.045)$.

The OLS regression results of our three models are reported in Table 3. Hypothesis 1 predicts a positive association between the external audit fee and the existence of an audit committee and this is tested in Model $1\left(\mathrm{R}^{2}=.809\right)$. There is a strong positive association between the level of audit fees and the existence of an audit committee (p $=.001$ ) and therefore Hypothesis 1 is supported.

Hypothesis 2 predicts a positive association between the external audit fee and the strength and activity of the audit committee. We measure strength and activity by the independence and expertise of the audit committee and the frequency of its meetings. The results for Model $2\left(\mathrm{R}^{2}=.814\right)$ show that only the frequency of audit committee meetings is significantly associated with audit fees $(p=.000)$. It appears from this model that the independence and expertise of audit committee members are not, on their own, significantly associated with the level of audit fees. Hence, Hypothesis 2 is only partially supported. This result is in contrast to that of Abbott et al. (2003) who report a significant positive association between audit fees and audit committee independence and expertise but no significant association between audit fees and the frequency of audit committee meetings. It also contrasts with that of Carcello et al. (2002) who find no association between audit committee characteristics and audit fees when they include board variables in their model.

As both of these previous studies use more condensed audit fee models, we repeat our analysis replicating as closely as possible the two models used in these studies. First, 
we replicate Carcello et al. (2002) by omitting the control variables ${ }^{16}$ not used in that study and by adding a variable for the number of business segments used. The reduced model produces an $\mathrm{R}^{2}$ of .795 and the untabulated results are qualitatively consistent with those reported in Model 2. The number of board meetings is not significantly associated with audit fees $(\mathrm{p}=.328)$ and the number of audit committee meetings is significantly and positively associated with audit fees $(p=.000)$. Further, this result holds when we exclude those companies without an audit committee.

Second, we replicate the Abbott et al. (2003) model by omitting certain control variables, combining receivables and inventory into a single variable and, importantly, using dummy variables for the three audit committee variables. Again, our results are broadly consistent with those reported in Model 2, with the frequency of audit committee meetings being significantly and positively associated with audit fees $\left(\mathrm{p}=.001\right.$, overall $\mathrm{R}^{2}=.783$ ). This result also holds when those companies without an audit committee are excluded from the sample.

Abbott et al. (2003) posit a number of possible reasons for the differences between their results and those of Carcello et al. (2002). First, they suggest that Carcello et al. (2002) used a sample drawn from the Fortune 1000 companies which are larger in size than the population of SEC registered firms and hence may have less variation in their audit committee characteristics. Second, they note that there may be a nonresponse bias in Carcello et al. (2002) as the data relating to audit fees were obtained by questionnaire survey. Third, changes in the regulatory environment in the US

\footnotetext{
${ }^{16}$ These are debt, return on assets, big five auditor, opinion and mining. Carcello et al. (2002) also include an industry variable for utilities but our sample includes only three companies in this industry.
} 
during the middle and late 1990s have called for greater audit committee oversight and increased levels of disclosure concerning audit committee duties and responsibilities. These changes may therefore have strengthened the motivation of audit committees to monitor the external audit. Our contrasting findings could also be due to differences between the regulatory environment in Australia and the US. In the year 2000, the environment in Australia was more akin to that in the Carcello et al. (2002) study, with a lower level of awareness of the need for independence and expertise on the audit committee. Further, our sample is comprised of both large and small Australian companies and even the large ones are small by US standards (Holland and Ramsay, 2003). Some of these companies may have had trouble appointing independent directors with appropriate experience to be audit committee members. As a result, it is possible that audit committee diligence plays a larger role in Australian companies.

We further explore the association between audit committee effectiveness and audit fees in model 3, which shows that, while meeting frequency is highly significant ( $\mathrm{p}=$ .002), there is a negative 2-way interaction between independence and expertise ( $\mathrm{p}=$ .052) and a positive 3-way interaction between independence, expertise and frequency of meetings $(\mathrm{p}=.011)$. We explore these interactions by dividing our sample into two groups based on frequency of audit committee meetings ${ }^{17}$ and conducting simple effects tests. Neither independence nor expertise of members is significantly associated with audit fees in the high meeting frequency sample. In the low meeting frequency sample, expertise is positively associated with audit fees $(\mathrm{p}<.01)$ but only when independence is low. It seems from this additional analysis that the frequency 
of meetings has the most impact on audit fees. However, when meetings are less frequent and there are executive directors on the committee, committee members with accounting and finance expertise appear to demand a higher level of assurance. This suggests that expertise, independence and meeting frequency are complementary to one another and all play a role in enhancing audit committee effectiveness.

This result differs from that of Sharma (2003) who found, for a sample of large Australian companies, a significant association between audit fees and audit committee independence and expertise only when committee meetings were high. The contrasting results may be due to our larger and more varied sample of companies. Clearly, the relationships are complex and further research is needed to fully explore audit committee effectiveness and its association with audit fees.

Hypothesis 4 predicts a positive association between the external audit fee and the use of internal audit. Our results support this hypothesis, with the internal audit variable being significant across all three models (p-values ranging from .007 to .067). This supports the suggestion that entities use internal and external audit as complementary monitoring mechanisms to strengthen overall corporate governance.

\subsection{Additional Analysis}

We tested for the possibility of endogeneity among audit fees, Big Five auditor, audit committee and internal audit by conducting two-stage least squares regression

\footnotetext{
${ }^{17}$ We obtain broadly similar results regardless of whether we split the sample based on cutoffs of three meetings per year, four meetings per year or based on whether the meetings are above or below the mean of two meetings per year.
} 
models. The untabulated results indicate that, while endogeneity is not a problem in the case of Big Five auditor and internal audit, our audit committee variable appears to be endogenously related to audit fees. This finding supports the argument that a higher quality auditor (charging higher fees) may influence the board to use an audit committee. This endogeneous relationship is a possible limitation of our first model but ceases to be a problem in Models 2 and 3 where we substitute measures of audit committee effectiveness for the existence of an audit committee. In these models, there is no evidence of endogeneity between audit fees and audit committee characteristics. This supports our suggestion that there was a lower level of awareness of the need for independence and expertise on the audit committee in the year of our study.

Because the number of employees in internal audit is likely to be associated with the size of the company, it could be argued that our internal audit variable is simply another measure of size. As an alternative measure, we scaled the number of employees by total assets. While this internal audit measure is not significant at conventional levels for the full sample, it is significant at $\mathrm{p}<.05$ for all three models when we exclude those companies with no internal audit function. As a further test, we substituted the log of internal audit size for the raw variable and our results do not differ significantly from those reported.

It is also possible that the use of both internal audit and a Big Five auditor and the existence of an audit committee are jointly associated with the external audit fee. We explored this possibility in two ways. First, we conducted a principal components analysis and found that the three variables do not load onto a single factor. Second, 
we added interactions between the three variables to our models. In all cases, the interaction effects are not significantly associated with the level of audit fees.

As in our replication of Abbott et al. (2003), we also tested our models using dichotomous measures of audit committee independence, expertise and meeting frequency. For independence, we used a dummy variable with the value of one if all members of the committee were independent and zero otherwise. For expertise, our dummy variable was given the value of one if at least one member of the committee had accounting or finance expertise. For meeting frequency, we used a dummy variable with the value of one if three or more meetings were held during the year, and again, if four or more meetings were held. In all cases, our results are qualitatively similar to those reported.

Finally, we ran alternative versions of the models, substituting some of our control variables for others that have been used in audit fee models and omitting outliers from our sample. For example, we substituted long term debt for non-current liabilities; we combined receivables and inventory together; we substituted current assets divided by total assets and current assets less inventory divided by current liabilities for receivables and inventory (Craswell et al., 1995). We further tested our models after omitting some firms with extreme values for total assets and negative returns on equity. In all cases, the results obtained do not differ significantly from those reported in the paper. 


\section{Conclusion}

Previous research on the relation between audit fees and audit committees and the use of internal audit has been inconclusive and provided conflicting results. The results of the current study suggest that, in Australia, firms with higher audit fees are more likely to have an audit committee and use a greater level of internal auditing. The results also suggest that, of the audit committee characteristics tested in the study, the frequency of meetings appears to have the most influence on audit fees. However, our results also show a 3-way interaction effect between audit committee characteristics. Further exploration of this effect suggests that audit committee expertise is positively related to audit fees but only when both meeting frequency and independence are low. This result is consistent with audit committee members with accounting and finance expertise demanding a higher level of assurance in these circumstances, leading to an increase in audit fees. This points to a complementary relationship between independence, expertise and frequency of meetings and suggests that the role that these characteristics play in enhancing audit committee effectiveness with respect to the external audit is a complex one.

Our findings imply that audit committees, internal audit and external audit are complementary mechanisms within the governance framework. This finding is not necessarily inconsistent with that of Felix et al. (2001) who report a negative association between audit fees and the auditor's assessment of the level of internal audit contribution to the external audit. This is because a large internal audit function is likely to be engaged in a range of monitoring, governance and risk management activities that are much broader in scope than those undertaken by the external auditor (Carey et al., 2000b). While internal audit may substitute for external audit work, our 
findings suggest that firms with large internal audit functions also engage in a higher overall level of monitoring.

Our study is particularly important in view of the large corporate collapses which have demonstrated problems with the quality of financial reporting and auditing. It has implications for those involved in corporate governance as it shows that companies with effective audit committees and internal audit functions also spend more on external auditing. Further, our findings indicate that it may not be appropriate to generalise the results of overseas studies to the Australian environment.

While our study makes an important contribution to the governance debate, there are a number of limitations that should be borne in mind and these provide opportunities for further research. The number of employees in internal audit may not be a good measure of the use of internal audit as it does not take into account the use of outsourcing or of secondment of employees into internal audit on a temporary basis. The size of the internal audit budget could be used in future research. There are also limitations with our measures of audit committee effectiveness. More refined measures of independence, expertise and diligence of audit committee members could be developed and used in future studies. Further, our research models do not indicate causality between the variables tested. Research is therefore needed to distinguish between supply side and demand side effects on audit fees and to unravel the complex interrelationships between the various monitoring mechanisms. 


\section{REFERENCES}

Abbott, L.J., S. Parker, G. F. Peters, and K. Raghunandan, 2003, The association between audit committee characteristics and audit fees, Auditing: A Journal of Practice \& Theory 22, 17-32.

Abbott, L.J., S. Parker, and G.F. Peters, 2004, Audit committee characteristics and restatements, Auditing: A Journal of Practice \& Theory 23, 69-87.

Aiken, L. S., and S. G. West, 1991, Multiple regression: Testing and interpreting interaction (Sage Publications, Newbury Park, California).

Australian Accounting Research Foundation, Australian Institute of Company Directors and Institute of Internal Auditors - Australia, 2001, Audit committees: Best practice guide $2^{\text {nd }}$ ed (Institute of Internal Auditors, Sydney).

Australian Stock Exchange (ASX) Corporate Governance Council, 2003, Principles of good corporate governance and best practice recommendations (ASX, Sydney).

Baxter, P., and J. Pragasam, 1999, Audit committees: One size fits all? Australian CPA (April), 42-43.

Beasley, M.S., J.V. Carcello, D.R. Hermanson, and P.D. Lapides, 2000, Fraudulent financial reporting: Consideration of industry traits and corporate governance mechanisms, Accounting Horizons 14, 14-21.

Blue Ribbon Committee on Improving the Effectiveness of Corporate Audit Committees (BRC), 1999, Report (NYSE, New York).

Brody, R.G., and D.J. Lowe, 2000, The new role of the internal auditor: Implications for internal auditor objectivity, International Journal of Auditing 4, 169-176.

Cadbury Committee, 1992, Report of the committee on the financial aspects of corporate governance (Gee: London).

Carcello, J. V., and T. L. Neal, 2000, Audit committee composition and auditor reporting, The Accounting Review 75, 453-467.

Carcello, J.V., D.R. Hermanson, T.L. Neal, and R.A. Riley, Jr., 2002, Board characteristics and audit fees, Contemporary Accounting Research 19, 365-384.

Carey, P., A. Craswell, and R. Simnett, 2000a, The association between the external audit fee and external auditors reliance on the work of internal audit, Working paper (Monash University, Victoria).

Carey, P., R. Simnett, and G. Tanewski, 2000b, Voluntary demand for internal and external auditing by family businesses, Auditing: A Journal of Practice \& Theory 19 (Supplement), 37-51. 
Casterella, J.R., J.R. Francis, B.L. Lewis, and P.L. Walker, 2004, Auditor industry specialization, client bargaining power, and audit pricing, Auditing: A Journal of Practice \& Theory 23, 123-140.

Chan, P., M. Ezzamel, and D. Gwilliam, 1993, Determinants of audit fees for quoted UK companies, Journal of Business Finance and Accounting 20, 765-773.

Collier, P., and A. Gregory, 1996, Audit committee effectiveness and the audit fee, The European Accounting Review 5, 177-198.

CLERP 9, 2004, The Corporate Law Economic Reform Program (Audit Reform and Corporate Disclosure) Act 2004 (Commonwealth of Australia: Canberra).

Coulton, J., A. Craswell, and S. Taylor, 2001, Do board characteristics influence audit fees? Working paper (University of Technology, Sydney and University of Sydney).

Craswell, A. T., and J. R. Francis, 1999, Pricing initial audit engagements: A test of competing theories, The Accounting Review 74, 2001-216.

Craswell, A.T., J.R. Francis, and S.L. Taylor, 1995, Auditor brand name reputations and industry specializations, Journal of Accounting and Economics 20, 297-322.

Davidson, R., J. Goodwin, and P. Kent, 2005, Internal governance structures and earnings management, Accounting and Finance forthcoming.

DeZoort, F.T., and S. Salterio, 2001, The effects of corporate governance experience, financial-reporting and audit knowledge on audit committee members' judgments, Auditing: A Journal of Practice \& Theory 20, 31-47.

Elliott, R. K., and A. R. Korpi, 1978, Factors affecting audit fees, Appendix Commission on auditors' responsibilities, in M.F. Shakun, Cost-Benefit Analysis of Auditing, Research Study No. 3 (AICPA, New York).

Felix,W. L. Jr, A.A. Gramling, and M. J. Maletta, 2001, The contribution of internal audit as a determinant of external audit fees and factors influencing this contribution, Journal of Accounting Research 39, 513-534.

Ferguson, A., J.R. Francis, and D.J. Stokes, 2003, The effects of firm-wide and officelevel industry expertise on audit pricing, The Accounting Review 78, 429-448.

Firth, M., 1997, The provision of non-audit services and the pricing of audit fees, Journal of Business Finance and Accounting 24, 511-525.

Francis, J.R., 1984, The effect of audit firm size on audit prices: A study of the Australian market, Journal of Accounting and Economics 6, 133-151.

Francis, J. R., and D. T. Simon, 1987, A test of audit pricing in the small-client segment of the U.S. audit market, The Accounting Review 62, 145-157.

Gerrard, I., K. Houghton, and D. Woodliff, 1994, Audit fees: The effects of auditee, auditor and industry differences, Managerial Auditing Journal 9, 3-11. 
Goddard, A. R., and C. Masters, 2000, Audit committees, Cadbury Code and audit fees: an empirical analysis of UK companies, Managerial Auditing Journal 15, 358-371.

Goodwin, J., and P. Kent, 2003, Factors affecting the voluntary use of internal audit, Paper presented at the Annual Meeting of the American Accounting Association, Hawaii.

Goodwin, J., and L. Munro, 2004, The impact of audit committee meeting frequency on the external audit: Perceptions of Australian auditors, Working paper (Queensland University of Technology).

Hay, D., and W. R. Knechel, 2002, Evidence on the associations among elements of control and external assurance, Working paper (University of Florida, Gainesville).

Holland, D., and A. Ramsay, 2003, Do Australian companies manage earnings to meet simple earnings benchmarks? Accounting \& Finance 43 (1), 41-62.

Jaccard, J., and R. Turrisi, 2003, Interaction effects in multiple regression, Second Edition, (Sage Publications, Thousand Oaks, California).

Jack, A., 1993, Audit Committees: A guide for non-executive directors (The Institute of Chartered Accountants in England and Wales, London).

Leung, P., B. Cooper, and P. Robertson, 2004, The role of internal audit in corporate governance and management (RMIT Publishing, Melbourne).

McElveen, M., 2002, New rules, new challenges, Internal Auditor (December), 40-47.

New York Stock Exchange Corporate Accountability and Listing Standards Committee (NYSE), 2002, Report (NYSE, New York).

Nofsinger J., and K. Kim, 2003, Infectious Greed (Financial Times Prentice Hall: Upper Saddle River, NJ).

Oppenheim, A.N., 1966, Questionnaire design and attitude measurement (Heinmann Books, New York).

PricewaterhouseCoopers, 1999, Audit committees: Good practices for meeting market expectations (PricewaterhouseCoopers).

Sharma, D.S., 2003, The efficacy of audit committee monitoring of audit quality: Tests of main and interaction effects, Paper presented at AFAANZ Conference, Brisbane, Australia.

Simunic, D.A., 1980, The pricing of audit services: Theory and evidence, Journal of Accounting Research 18, 161-190.

Stein, M. T., D. A. Simunic, and T. B. O’Keefe, 1994, Industry differences in the production of audit services, Auditing: A Journal of Practice and Theory (Supplement), 128-142. 
Von Nessen, P., 2003, Corporate governance in Australia: Converging with international developments, Australian Journal of Corporate Law 15 (3), 189224.

Wallace, W., 1984, A times series analysis of the effect of internal audit activities on external fees (The Institute of Internal Auditors Research Foundation, Altamonte Springs, FL). 
Table 1

Descriptive statistics $(n=401)$

\begin{tabular}{|c|c|c|c|c|c|}
\hline \multicolumn{6}{|c|}{ Panel A: Continuous variables } \\
\hline Variable & Minimum & Maximum & Mean & $\begin{array}{l}\text { Standard } \\
\text { deviation }\end{array}$ & Median \\
\hline Audit fee (\$) & 2000 & $6,601,000$ & 191,129 & 553,774 & 53,000 \\
\hline Total assets (\$000s) & 65 & $30,339,000$ & 545,423 & $2,477,718$ & 34,986 \\
\hline No. of subsidiaries & 0 & 440 & 16 & 39 & 6 \\
\hline $\begin{array}{l}\text { Proportion of } \\
\text { foreign subsidiaries }\end{array}$ & 0.00 & 1.00 & 0.18 & 0.25 & 0.00 \\
\hline $\begin{array}{l}\text { Non-current } \\
\text { liabilities/assets }\end{array}$ & 0.00 & 1.46 & 0.15 & 0.18 & 0.07 \\
\hline Receivables/assets & 0.00 & 0.61 & 0.11 & 0.13 & 0.05 \\
\hline Inventories/assets & 0.00 & 0.72 & 0.08 & 0.12 & 0.02 \\
\hline Return on assets & -8.86 & 0.61 & -0.07 & 0.51 & 0.00 \\
\hline Board independence & $0 \%$ & $100 \%$ & $62 \%$ & $19 \%$ & $67 \%$ \\
\hline Board meetings & 2 & 35 & 10.90 & 4.74 & 11.00 \\
\hline AC independence & $0 \%$ & $100 \%$ & $46 \%$ & $40 \%$ & $50 \%$ \\
\hline AC expertise & $0 \%$ & $100 \%$ & $29 \%$ & $34 \%$ & $25 \%$ \\
\hline AC meetings & 0 & 14 & 2 & 2 & 2 \\
\hline Internal audit & 0 & 50 & 1 & 4.20 & 0 \\
\hline \multicolumn{6}{|c|}{ Panel B: Dichotomous variables } \\
\hline Variable & Yes & $\%$ & No & & $\%$ \\
\hline Loss in last 3 years & 269 & 67.1 & 132 & & 32.9 \\
\hline Big five auditor & 271 & 67.6 & 130 & & 32.4 \\
\hline Qualified opinion & 42 & 10.5 & 35 & & 89.5 \\
\hline Mining industry & 119 & 29.7 & 28 & & 70.3 \\
\hline Audit committee & 308 & 76.8 & 93 & & 23.2 \\
\hline
\end{tabular}

Proportion of foreign subsidiaries = ratio of number of foreign subsidiaries to number of subsidiaries. Return on assets $=$ earnings before interest and tax divided by total assets.

Board independence $=$ the percentage of non-executive directors on the board

Board meetings $=$ the number of board meetings held during the year

AC independence $=$ the percentage of audit committee members who are non-executive directors with no related party transactions

AC expertise = the percentage of audit committee members who have accounting, finance or business qualifications (such as an accounting-related degree or a professional accounting qualification)

AC meetings = the number of meetings of the committee held during the year

Internal audit $=$ the number of employees in internal audit ( 0 when there is no internal audit function) Loss in 3 years = a dummy variable given the value 1 if the company has reported a loss in any of the three years prior to 2000, and 0 otherwise. 
Big five auditor $=$ a dummy variable given the value 1 when a Big Five auditor is used, and 0 otherwise.

Qualified opinion = a dummy variable given the value 1 when the audit report is qualified, and 0 otherwise.

Mining industry = a dummy variable given the value 1 when the company is in the mining industry and 0 otherwise.

Audit committee = a dummy variable given the value 1 for the existence of an audit committee, and 0 otherwise. 


\section{Table 2}

Correlation coefficients for the variables in the model $^{\wedge}$

\begin{tabular}{|c|c|c|c|c|c|c|c|c|c|c|c|c|c|c|c|c|c|c|}
\hline & Audit fee & Size & No. of subs. & \begin{tabular}{|l}
$\begin{array}{l}\text { Foreign } \\
\text { subs. }\end{array}$ \\
\end{tabular} & \begin{tabular}{|l|} 
NC liabs/ \\
assets
\end{tabular} & \begin{tabular}{|l|} 
Rec./ \\
assets
\end{tabular} & Inv./ assets & ROA & \begin{tabular}{|l|}
$\begin{array}{l}\text { Loss in } 3 \\
\text { years }\end{array}$ \\
\end{tabular} & \begin{tabular}{|l}
$\begin{array}{l}\text { Big } 5 \\
\text { auditor }\end{array}$ \\
\end{tabular} & \begin{tabular}{|l|}
$\begin{array}{l}\text { Qualified } \\
\text { opinion }\end{array}$ \\
\end{tabular} & Mining & \begin{tabular}{|l|l} 
Board \\
indep.
\end{tabular} & \begin{tabular}{|l|l|}
$\begin{array}{l}\text { Board } \\
\text { meetings }\end{array}$ \\
\end{tabular} & $\begin{array}{l}\text { Audit } \\
\text { comm. }\end{array}$ & AC indep. & AC exp. & AC meet. \\
\hline Audit fee & 1.000 & & & & & & & & & & & & & & & & & \\
\hline Size & $0.824 * *$ & 1.000 & & & & & & & & & & & & & & & & \\
\hline No. of subs. & $0.744 * *$ & $0.680^{*}$ & 1.000 & & & & & & & & & & & & & & & \\
\hline Foreign subs. & $0.360 * *$ & $0.218^{* *}$ & $0.320^{* *}$ & 1.000 & & & & & & & & & & & & & & \\
\hline NC liabs./assets & $0.386 * *$ & $0.462 * *$ & $0.285^{* *}$ & 0.104* & 1.000 & & & & & & & & & & & & & \\
\hline Rec./assets & $0.306 * *$ & $0.110^{*}$ & $0.204 * *$ & $0.169 * *$ & -0.001 & 1.000 & & & & & & & & & & & & \\
\hline Inv./assets & $0.231 * *$ & $0.182 * *$ & $0.133^{* *}$ & $0.132 * *$ & 0.018 & $0.364^{* *}$ & 1.000 & & & & & & & & & & & \\
\hline ROA & $0.203 * *$ & $0.319 * *$ & $0.123 *$ & 0.066 & $0.105^{*}$ & 0.049 & 0.097 & 1.000 & & & & & & & & & & \\
\hline Loss in 3 years & $-0.447 * *$ & $-0.509 * *$ & $-0.354^{* *}$ & -0.084 & $-0.224 *$ & $-0.209 * *$ & $-0.240^{* *}$ & $-0.188^{* *}$ & 1.000 & & & & & & & & & \\
\hline Big 5 auditor & $0.379 * *$ & $0.354^{* *}$ & $0.220^{* *}$ & 0.115* & $0.165^{* *}$ & 0.018 & 0.096 & $0.141^{* *}$ & $-0.202 *$ & 1.000 & & & & & & & & \\
\hline Qualified opinion & $-0.184 * *$ & $-0.257 * *$ & $-0.128^{*}$ & -0.009 & -0.098 & $-0.106 *$ & -0.084 & $-0.241^{* *}$ & $0.240 * *$ & -0.059 & 1.000 & & & & & & & \\
\hline Mining & $-0.281^{* *}$ & $-0.166^{* *}$ & $-0.149 * *$ & -0.006 & -0.048 & $-0.364 * *$ & $-0.294 * *$ & -0.029 & $0.246^{* *}$ & -0.028 & $0.134 * *$ & 1.000 & & & & & & \\
\hline Board indep. & $0.180^{* *}$ & $0.131^{*}$ & 0.095 & 0.030 & 0.085 & 0.048 & -0.027 & 0.030 & $-0.133 * *$ & 0.045 & -0.077 & $-0.144 * *$ & 1.000 & & & & & \\
\hline Board meetings & $0.118^{*}$ & 0.096 & 0.039 & -0.040 & 0.038 & 0.111* & 0.040 & 0.086 & -0.021 & 0.011 & 0.005 & -0.053 & 0.049 & 1.000 & & & & \\
\hline Audit comm. & $0.441^{* *}$ & $0.397^{* *}$ & $0.259 * *$ & $0.133^{* *}$ & $0.249 * *$ & $0.206^{* *}$ & $0.192^{* *}$ & $0.177^{* *}$ & $-0.272 * *$ & $0.162 * *$ & $-0.121 *$ & $-0.277 * *$ & $0.214^{* *}$ & $0.183^{* *}$ & 1.000 & & & \\
\hline AC indep. & $0.369 * *$ & $0.377^{* *}$ & $0.222^{* *}$ & $0.159 * *$ & $0.207^{* *}$ & $0.128^{* *}$ & 0.082 & $0.166^{* *}$ & $-0.279 * *$ & $0.149 * *$ & $-0.187 * *$ & $-0.223^{* *}$ & $0.311^{* *}$ & 0.018 & $0.579 * *$ & 1.000 & & \\
\hline AC exp. & $0.284^{* *}$ & $0.294 * *$ & $0.176^{* *}$ & 0.088 & $0.194 * *$ & 0.094 & $0.123^{* *}$ & $0.102 *$ & $-0.293^{* *}$ & 0.091 & $-0.099 *$ & $-0.238 * *$ & $0.170^{* *}$ & $0.153^{* *}$ & $0.398^{* *}$ & $0.289 * *$ & & \\
\hline AC meet. & $0.564 * *$ & $0.534^{* *}$ & $0.402^{* *}$ & $0.138^{* *}$ & $0.280^{* *}$ & 0.123* & $0.135^{* *}$ & $0.128 *$ & $-0.382 * *$ & $0.231 * *$ & $-0.138 * *$ & $-0.118^{*}$ & $0.152^{* *}$ & $0.188^{* *}$ & $0.588^{* *}$ & $0.382 * *$ & 1.000 & 1.000 \\
\hline Internal audit & $0.411^{* *}$ & $0.447 * *$ & $0.324 * *$ & 0.113* & $0.136^{* *}$ & -0.009 & 0.064 & 0.063 & $-0.159 * *$ & -0.037 & -0.065 & -0.070 & 0.046 & 0.041 & $0.137 * *$ & 0.135** & 0.069 & $0.361^{* *}$ \\
\hline
\end{tabular}

$\wedge$ Pearson correlations are adjusted automatically by SPSS when variables are dichotomous. 
** Correlation is significant at the 0.01 level (2 tailed)

* Correlation is significant at the 0.05 level (2 tailed)

Audit fee $=$ natural log of audit fees

Size $=$ natural log of total assets

No. of subs. = square root of number of subsidiaries

Foreign subs. $=$ ratio of number of foreign subsidiaries to number of subsidiaries

NC liabs/assets $=$ ratio of non-current liabilities to total assets

Rec./assets $=$ ratio of receivables to total assets

Inv./assets $=$ ratio of inventory to total assets

ROA = earnings before interest and tax divided by total assets

Loss in 3 years = a dummy variable given the value 1 if the company has reported a loss in any of the three years prior to 2000 , and 0 otherwise

Big 5 auditor $=$ a dummy variable given the value 1 when a Big Five auditor is used, and 0 otherwise

Qualified opinion = a dummy variable given the value 1 if the audit opinion is qualified, and 0 otherwise

Mining = a dummy variable given the value 1 if the firm is in the mining industry, and 0 otherwise

Board indep. $=\%$ of non-executive directors on the board

Board meetings $=$ the number of board meetings held during the year

Audit comm. = a dummy variable given the value 1 for the existence of an audit committee, and 0 otherwise

AC indep. = the percentage of audit committee members who are non-executive directors with no related party transactions

$\mathrm{AC}$ exp. $=$ the percentage of audit committee members holding accounting, finance or business qualifications (such as an accounting-related degr 